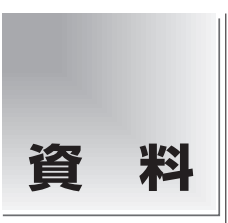

論文受付

2011 年 6 月28日

論文受理

2011 年 8 月11日

Code No. 261

\section{MRI 検查におけるインプラントと 体内外金属物質の情報集約}

\author{
小林昌樹・小林正人・染野竜也・内山弘実・小野祐樹
}

長野市民病院診療技術部診療放射線科

\section{緒 言}

国内において magnetic resonance imaging(MRI)装 置が臨床に活用されてから現在に至り, $0.25 \mathrm{~T}$ から $3.0 \mathrm{~T}$ までさまざまな磁場強度の診断用 MRI 装置が 数多く普及している。しかし, 装置の普及に伴い MRI 検査時に最も問題となるインプラント (例 : 脳動 脈瘤手術用クリップ，人工股関節大腿骨コンポーネ ントなど)や体内外金属物質(例：医療用嘴管および 体液誘導管, 子宮内避妊用具など)に関しての情報や 指針などは少なく，MRI 検査の可否が施設間におい て異なることがある。また，インプラントと体内外金 属物質にはさまざまな材質が使用されているため, 医療現場においては MRI 検査に関する事前問診を徹
底している施設は多分にあると思われる。しかし, 事 前問診上，詳細不明なインプラントや体内外金属物 質に遭遇した際，特にわれわれは留意して検査を施 行することが至当であると考えるが，最終的に MRI 検査が可能か否かの判断に当惑する場面がある。そ のため, インプラントや体内外金属物質の詳細が不明 のまま検査を施行し, 有害事象(吸着, 熱傷など) ${ }^{1,2)}$ を起してしまった事例も少なくないと聞く3).

そこで, 長野県 MR 研究会 II が先駆けとなり, 数 年前から当院を中心とし近隣施設の協力の元, イン プラントと体内外金属物質の「製品名」，「製品の主な 材質」,「MRI 検査への適合性」，製品の「製造元・販 売元・取扱店」，製品および材質に関する「資料(医療

\title{
Collection of Information Regarding Implants, Internal and External Metallic Objects for MRI Examinations
}

\author{
Masaki Kobayashi, Masato Kobayashi, Tatsuya Someno, \\ Hiromi Uchiyama, and Yuuki Ono \\ Nagano Municipal Hospital \\ Received June 28,2011; Revision accepted August 11, 2011; Code No. 261
}

\section{Summary}

In Japan, various types of MRI equipment, having varying magnetic field strengths, are widely used. However, the biggest problem encountered while utilizing an MRI is the scarcity of information and guidelines pertaining to implants, internal, and external metallic objects. This leads to uncertainty when an unspecified object is encountered during an examination andcreates the possibility of performing an ambiguous MRI. Therefore, this study classified a range of objects into 12 categories using database management software. An attempt was made to create an environment where reference and comparison of products could be performed. This study also investigated the ways and extent to which medical equipment package inserts reference the MRI. With the co-operation of various corporations and the use of information such as medical equipment package inserts, product information was collected and an environment for the reference and comparison of products became available. In addition, it became apparent while examining these package inserts that orthopedic products had the least information available. It is likely that this information will be useful in medical settings and this kind of database will become increasingly necessary in the future.

Key words: magnetic resonance imaging (MRI), implant, metal material 
機器添付文書(以下，添付文書)や製品カタログな ど)」,「材質情報」,「備考(前述以外の情報)」の集約 を行い，データベース管理ソフトによって集約情報の 検索，参照を行える環境を整えるとともに添付文書 上における MRIに関する記載状況も合わせて調査し たので報告する.

\section{1. 方 法}

\section{1-1 情報の集約方法}

インプラントと体内外金属物質を独自に，コイル関 連製品，クリップ関連製品，シャントバルブ関連製 品, ステント関連製品, フィルタ関連製品, 皮下用 ポート関連製品, 心臓関連製品, 整形外科関連製 品, 刺激電極関連製品, 歯科関連製品, 化粧品関連 製品，その他製品に分類 (12 種類)をし，製品の製造 元・販売元・取扱店のホームページ (homepage; HP) も しくは, 独立行政法人医薬品医療機器総合機構 (Pharmaceuticals and Medical Devices Agency; PMDA)の医薬品医療機器情報提供 HP より情報の集 約を行った。各 HPでは，主に「製品名」，製品の「製 造元・販売元 · 取扱店」, 「資料」を入手し, 前述項目 以外もしくは情報不足部分に関しては直接，製造元 · 販売元・取扱店と連絡を交わし詳細な情報を入手し集 約を行った。今回は添付文書および製造元・販売元・ 取扱店からの情報を基本とし，データベースの作成 を行った。インプラントと体内外金属物質の情報集約 には Microsoft Excel を使用し, 情報の検索, 参照に は FileMakerを使用した。

\section{1-2 使用ソフト}

Microsoft Office Excel 2007(Excel 2007), FileMaker Pro 8.5 を使用した。

\section{2. 結 果}

\section{2-1 インプラントと体内外金属物質の集約数}

コイル関連製品 24 品目, クリップ関連製品 5 品 目，シャントバルブ関連製品 10 品目，ステント関連製 品 114 品目, フィルタ関連製品 8 品目, 皮下用ポート 関連製品 12 品目，心茞関連製品 20 品目，整形外科 関連製品 294 品目，刺激電極関連製品 15 品目，歯科 関連製品 4 品目，化粧品関連製品 10 品目，その他製 品 34 品目, 合計 550 品目の集約を行うことができた.

\section{2-2 インプラントと体内外金属物質の検索, 参照に関する概要}

Fig. 1 が今回 FileMaker Pro 8.5 で作成を行った検 索，参照画面と概要になる。(1)は製品名もしくはカテ ゴリからの検索を行う部分になる。製品名検索の場

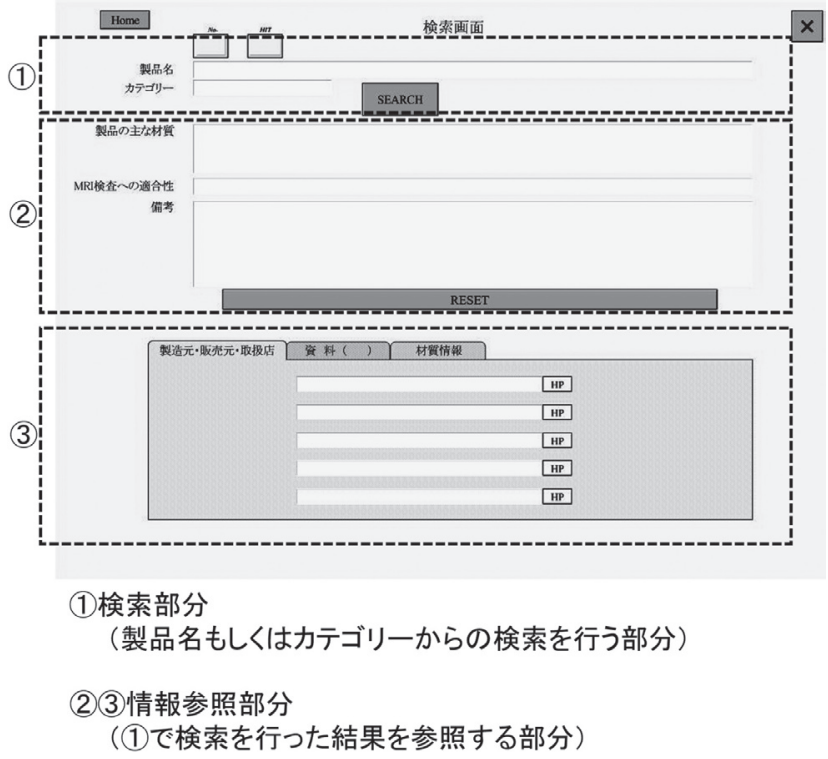

Fig. 1 A search and reference screen.

合，正確な製品名はもちろん，製品名の一部分を入 力することで該当するすべての製品を検索することが できる。もう一つの検索方法としてカテゴリからの検 索を行うことができる。 カテゴリ検索とは，今回 12 分類したインプラントと体内外金属物質を関連製品 単位で表示を行い，登録されている全製品名を表示 することができる機能である。全製品名から該当する 製品を選択することで製品名検索と同様の検索結果 を得ることができる(Fig. 2)，このように検索に関して は 2 通りの方法がある。

次に(2)と(3)に関しては, (1)で検索を行った結果を 参照する部分になる。(2)では,「製品の主な材質」, $\lceil M R I$ 検査への適合性」，「備考」を参照することがで きる(Fig. 3)。「製品の主な材質」とは，文字通り製品 に使用されている主な材質を参照する箇所になる。 続いて「MRI 検査への適合性」とは，添付文書を基準 とし独自に「添付文書上可能」，「添付文書上可能(条 件付き)」，「添付文書上不可」，「添付文書上記載な し」，「添付文書入手不可」の 5 項目から「MRI 検査へ の適合性」を参照することができる箇所になる，次に 「備考」とは，MRIに関する記載の抜粋(製品に関する 資料からの抜粋)や製品の製造元・販売元 ·取扱店か らの MRI 検査に関する対応等が参照できる箇所と なっている.

次に(3)のタブで区切られている部分では，製品の 「製造元・販売元・取扱店」，製品および材質に関する 「資料(添付文書や製品カタログなど)」,「材質情報」 を参照することができる(Fig. 4).

製品の「製造元・販売元・取扱店」は最大 5 社まで 登録されており，HP をもつ製造元・販売元・取扱店 


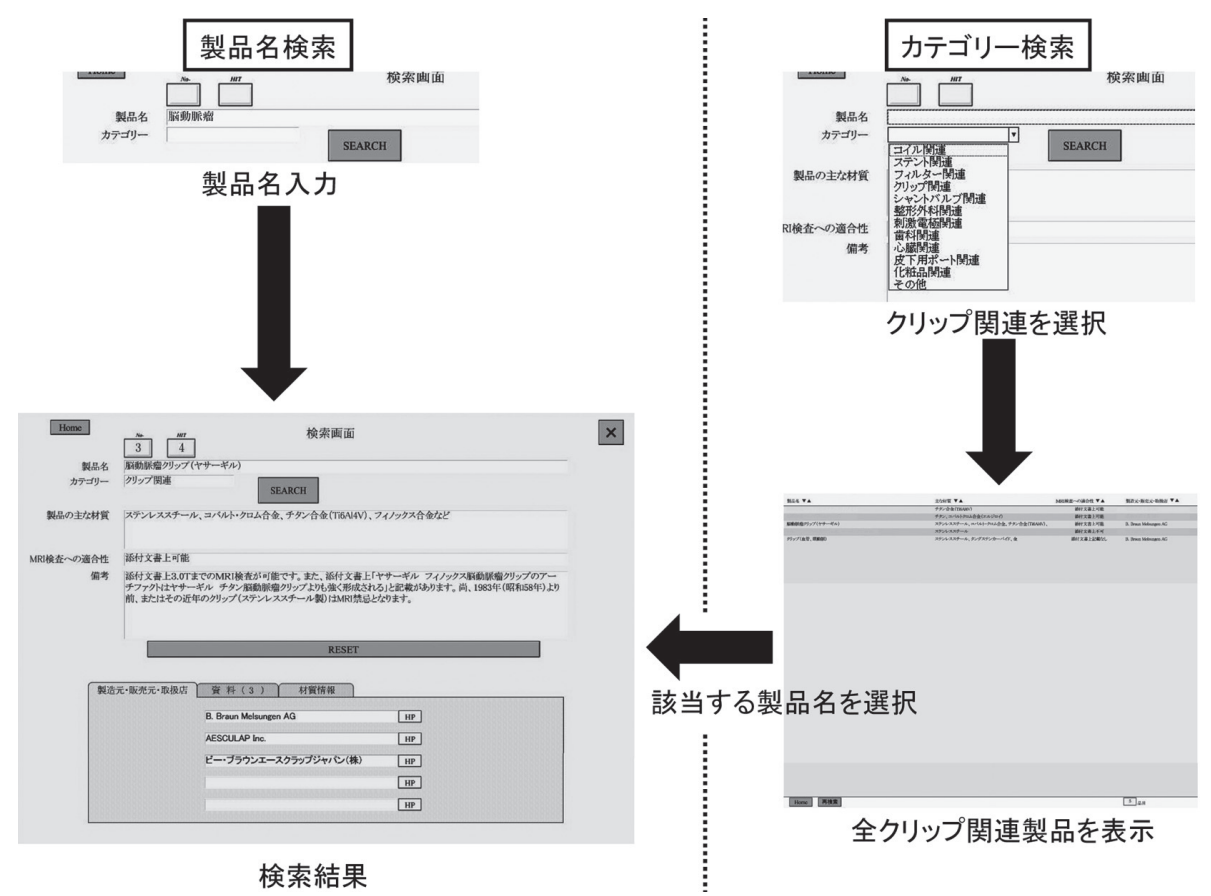

Fig. 2 Retrieval method.



Fig. 3 (2) The details of the information reference part.

に関しては，HP ボタンを押すことにより HP ヘジャン プをすることが可能となっている(ただし，インター ネットへの接続がされている端末で検索, 参照を 行っている場合のみ可能)，そのため直接，製造元 販売元・取扱店への問い合わせや製品の概要などを容 易に参照することが可能となっている(ただし，企業 によってはユーザ identification(ID)とパスワードを登 録しなければ製品の概要が参照できない場合があ る). 次に，製品および材質に関する「資料(添付文書 や製品カタログなど)」は最大 6 種類までの資料を参 照することができる。前述にも記載したが添付文 書, 製品カタログのほか, 製造元・販売元・取扱店か らの製品資料，製品の材質に関する基本的な資料等 を参照することができる。これらの資料は portable document format $(\mathrm{PDF})$ ファイルもしくは WEB で構成 をしているため, 資料ボタンをクリックした際は PDF
ファイルを参照することができ，WEB ボタンをクリッ クした際はインターネットが起動し情報を参照するこ とができる(ただし，WEBに関してはインターネット への接続がされている端末で検索, 参照を行ってい る場合のみ可能)。最後に「材質情報」とは, (2)の「製 品の主な材質」の詳細を参照することができる箇所に なる、概要ではあるが，(1)の部分で製品の検索を行 い, (2)と(3)の部分で製品の情報を参照することがで きるシンプルな構成となっている。

\section{2-3 添付文書上における MRI に関する記載状況}

MRIに関する詳細な記載および何らかの記載があ る添付文書の割合は，コイル関連製品 $84 \%$ ，クリッ プ関連製品 $80 \%$ ，シャントバルブ関連製品 $83 \%$ ， ス テント関連製品 $86 \%$ ，フィル夕関連製品 $100 \%$ ，皮下 用ポート関連製品 $17 \%$ ，心臓関連製品 $88 \%$, 整形外 

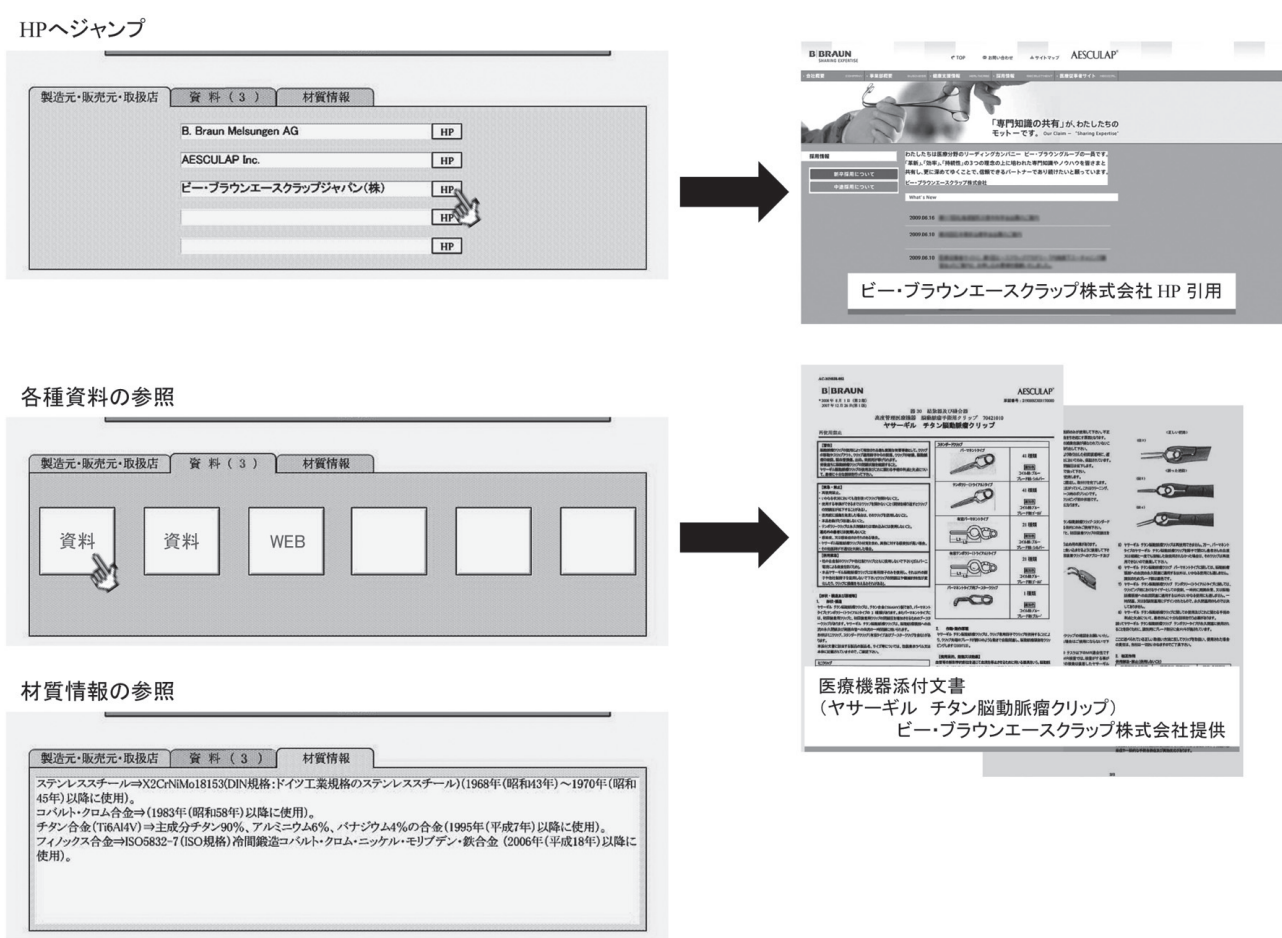

Fig. 4 (3) The details of the information reference part.
科関連製品 $2 \%$, 刺激電極関連製品 $100 \%$ ，歯科関連 製品 $33 \% ， そ の$ 他製品 $41 \%$ の割合で記載がされてい た。化粧品関連製品に関しては添付文書を入手でき ず記載状況は不明であった。

\section{3. 考 察}

\section{3-1 今後の課題}

今回の試みでは, 1997 年 12 月まで販売実績の あった製品(販売元からの情報)から 2010 年(添付文 書上の記載)までの製品が集約されている。ただし, 大半は 2000 年から 2010 年までの製品が主要となっ ている。また， $3.0 \mathrm{~T}$ 装置への適合性は添付文書およ び製造元・販売元・取扱店に確認を行っている. しか し, $3.0 \mathrm{~T}$ 装置への適合性を有する製品は, 今回の調 査において 550 品目中 73 品目のみであり $3.0 \mathrm{~T}$ 装置 への適合性を記載した添付文書および企業側からの 情報は未だそしいのが現状であった。

われわれが集約した製品は，存在するすべてのイ ンプラントや体内外金属物質を網羅している訳では なく, 数日後, 数力月後, 数年後には新製品の登場 や製品名, 材質の変更が予告なく行われる. 添付文 書においても同様に予告なく変更が行われるため, データベースの更新や修正時期を検討しなければな らない.

また, 最終判断となる「MRI 検査への適合性」およ び製品の製造元・販売元・取扱店からの MRI 検査に 関する対応を残念ながら, すべての製品に関して完
全に記載できた訳ではない。その主な原因として，添 付文書自体に記載がないこと，製造元・販売元・取扱 店側が材質の詳細を非公表にしたこと，製造元・販売 元・取扱店側が製品に関しては「病院にて判断してく ださい」や「MRI 製造元に確認をしてください」などと いった回答が大半であったこと，が挙げられる。これ ら 3 点の原因によって完全な記載ができなかった。た だし，このような製造元・販売元・取扱店だけではな く，中には数日から数力月を費やし，われわれが要求 した資料などを収集してくれた製造元・販売元・取扱 店や材質の詳細な情報を国外本社から入手し回答し た製造元・販売元・取扱店も少なくなかったのは事実 である。

今回のインプラントと体内外金属物質の情報集約 以外にも非常に興味深い結果を得ることができた。 それは，2-3「添付文書上における MRI に関する記載 状況」である．各カテゴリの母数には違いがあるもの の，整形外科関連製品に関しては記載状況が非常に 低いという事実と，歯科関連製品および皮下用ポート 関連製品に関しても同様に記載状況が低いことが明 らかとなった。これらの現状に関して整形外科関連, 歯科関連製品を取扱う製造元・販売元 · 取扱店へ確 認を行ったところ，「国外本社がMRIに関する記載 を行っていないため詳細が不明」といった回答や，わ れわれの質問に対して企業側からの回答がないと いった対応が大半であった[ただし，2011 年 7 月末日 現在, 整形外科関連製品を取扱う一部の企業では, 


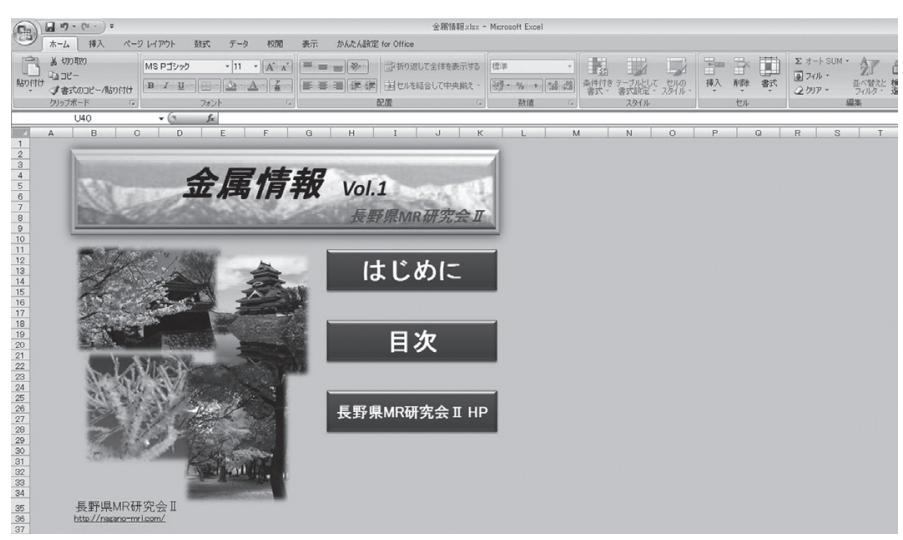

Fig. 5 Top screen of 2007 Excel versions.

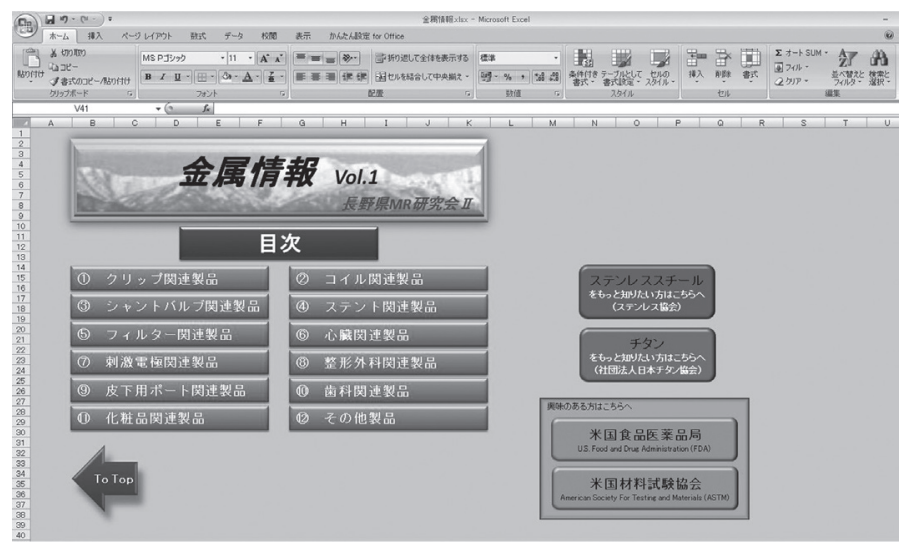

Fig. 6 Table of contents screen of 2007 Excel versions.

MRI に関する詳細な文言 $(M R I へ の$ 適合性, アーチ ファクト，発熱など)を順次, 添付文書へ記載を行っ ていく予定であるという情報が得られている]。しか し，皮下用ポート関連製品を取扱う製造元・販売元・ 取扱店に関しては現在のところ，添付文書改訂には 至ってはいないが改訂に取組む内容の回答を得るこ とができた，材質に金属製品を使用している限り，記 載すべき事柄(アーチファクト，発熱，移動)は十分に 考えられる。しかし，製造元・販売元・取扱店側の MRI 検査に関する認識度には温度差が感じられ，個 人的な問い合わせや要望には限界があった。今後, 高磁場強度へと変遷していく中, より一層 MRI 検査 への安全性を具現化する必要がある。そのためにも 添付文書への記載を徹底することが重要であり，最 難関な課題であると考える.

\section{3-2 CD 化への取組み}

今回, インプラントと体内外金属物質の集約情報 を参照させるために FileMaker を使用した。しかし，

FileMakerを保有する人，施設は少なく，限られた ユーザのみの情報となり，施設間における認識度に 相違が生じてしまうことが懸念された。そこで，現在
ではExcel 2007 を使用し，誰もが参照できる形態に 是正した. Excel 2007 バージョンでは, FileMakerの ように検索をする機能まで拡張させることはできな かったが，十分に情報を参照できる環境となってい る. Fig. 5 がExcel 2007 バージョンのトップ画面,

Fig. 6 がインプラントや体内外金属物質をカテゴリ分 類した目次画面である。前述で述べたように検索機 能がないため，登録されている全製品名および情報 が一度に表示される。Fig. 7 がそのレイアウトと概要 である。今回はExcel 2007 バージョンの詳細は割愛 させていただく.

Excel 2007 バージョンと FileMaker バージョンでは 容量的(約 $630 \mathrm{MB}$ )に差異はなく, Excel 2007 の保有 数と $\mathrm{CD}$ (700 MB 用) 1 枚分の容量というメリットか ら，近隣施設への CD 配布を視野に入れることが可 能となる. 長野県 MR 研究会 II の HP 上での検索, 参照も検討したが, それにはある程度の費用 (HP 上 での検索，参照の際はFileMakerでの運用を考えて いる) と製造元・販売元・取扱店側への了解などが必 要となるため, 現在では CD 化を第一選択とし検討 を行っている。これらの取組みが，実現した際は注 意事項を㛜守していただける施設に配布を考えてお 


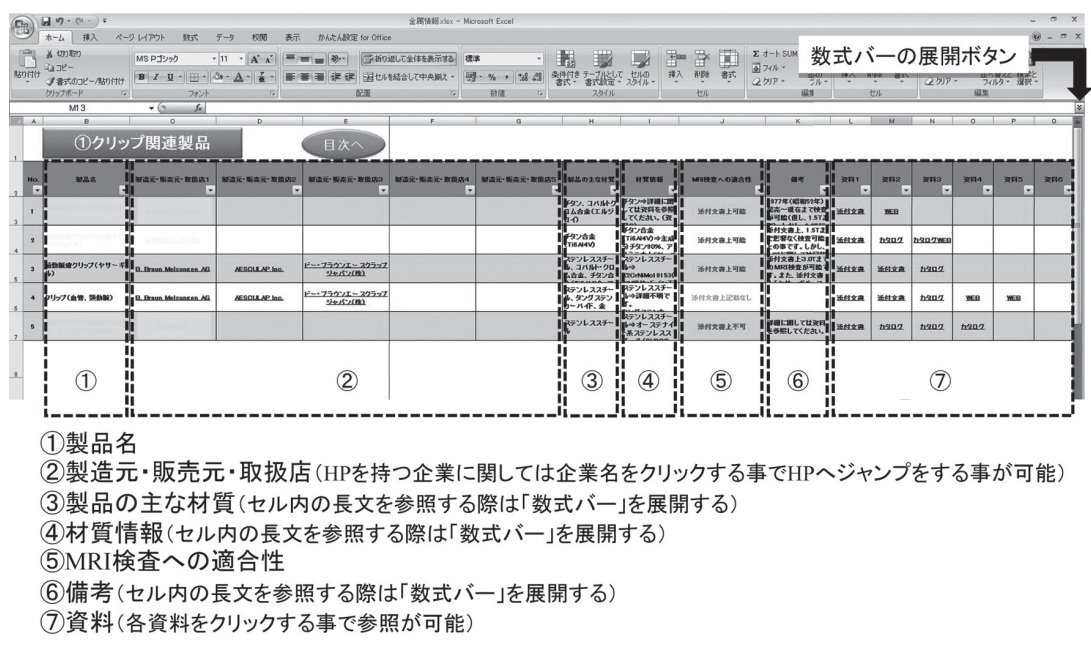

Fig. 7 The layout and summary of 2007 Excel versions.

り, これらの情報が些少でも医療現場で役立つことと MRI 検查の可否が施設間で異なることを払拭するこ とができれば幸いであると考える。

\section{4. 結 語}

われわれが携わるさまざまな検查，治療に関し て，安全管理が叫ばれている中でMRI 検査を安全 に施行するためには，インプラントや体内外金属物 質の情報は必須であり，施設間に打ける共通した認 識を持つことが肝要である ${ }^{4,5)}$. そのためにも，今後 このようなデータベースの重要性は高まると考えら れる。しかし，個人的な情報集約には時間的な制約 のほか，企業側の情報開示拒否等が存在する。そ のため, 日本放射線技術学会 (Japanese Society of Radiological Technology; JSRT)や日本磁気共鳴専門 技術者認定機構(Japan Authorize Organization for
Magnetic Resonance Technological Specialist; JMRTS) などの各種団体が情報集約の中心となりなお，われ われにさまざまな情報を発信するとともに，厚生労働 省や企業側に対し添付文書への記載を要望すると いった働きかけを期待する。

\section{謝 辞}

今回の集約にご協力いただいた，信州大学医学部 附属病院，JA 長野厚生連佐久総合病院，長野医療 生協長野中央病院，長野赤十字病院 (50 音順)の診療 放射線技師の皆様と情報提供にご協力いただいた， 各種企業製品担当の皆様に厚く御礼申し上げます.

な扮，本研究は第 37 回日本放射線技術学会秋季学 術大会(2009 年 10 月, 岡山)にて発表した.

\section{参考文献}

1) Muranaka H, Horiguchi T, Usui S, et al. Dependence of RF heating on SAR and implant position in a $1.5 \mathrm{~T}$ MR system. Magn Reson Med Sci 2007; 6(4): 199-209.

2) Muranaka H, Horiguchi T, Usui S, et al. Evaluation of RF heating on humerus implant in phantoms during 1.5T MR imaging and comparisons with electromagnetic simulation. Magn Reson Med Sci 2006; 5(2): 79-88.
3) 畑 雄一. MRI の安全性一体内埋め込久装置あるいは金 属について一。目磁医誌 1999; 19(5): 303-309.

4）土井 司, 橋田昌弘, 土橋俊男, 他. 高磁場 MRI とその 安全性 論文特集号. 日放技学誌 2008; 64(12)：14911491.

5）川光秀昭, 土橋俊男, 宮地利明, 他. 3T-MR 装置の安全 性. 日放技学誌 2008; 64(12): 1575-1599.

Fig. 1 検索㧍よび参照画面

Fig. 2 検索方法

Fig. 3 (2)情報参照部分の詳細

Fig. 4 (3)情報参照部分の詳細

Fig. 5 Excel 2007 バージョンのトップ画面

Fig. 6 Excel 2007 バージョンの目次画面

Fig. 7 Excel 2007 バージョンのレイアウトおよび概要 